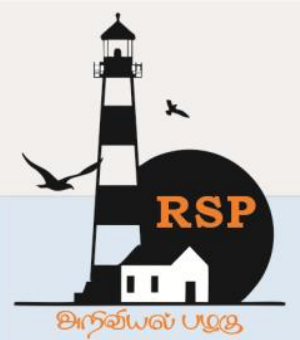

INTERNATIONAL RESEARCH JOURNAL ON ADVANCED SCIENCE HUB

ISSN : $2582-4376$
Open Access

RSP SCIENCE HUB

(The Hub of Research Ideas)

Available online at www.rspsciencehub.com

Special Issue of First International Conference on Advancements in Management, Engineering and Technology (ICAMET 2020)

\title{
The Challenges of Poverty, Types and Its Causes
}

\section{Dr. Sharath A $M$}

Lecturer, P.G Studies and Research in Economics, Kuvempu University, Shankaraghatta, Shimoga,

Karnataka.

sharath.am6@gmail.com

\begin{abstract}
Destitution is a monetary state where individuals are encountering shortage or the absence of specific products that are required for the lives of people like cash and material things. Accordingly, destitution is a multifaceted idea comprehensive of social, monetary and political components. Destitution has become an incredible issue in our reality. Despite the fact that numerous associations have been made to find answers to this issue, no one could fully spare our reality from destitution. The most well-known fact that we can understand when contemplating destitution data is that neediness normally exists in the development of nations. Around 25 percent of the population currently lives in deteriorated need, according to them. Undoubtedly, even the assembly of India has yielded that around 20 crore people in India live in a state of pathetic destitution with no permission to minimized drinking water, purification, and two complete meals. In light of these issues I should think about the challenges of desperation and its causes in India and its sorts.
\end{abstract}

Keywords: Poverty, Causes and Types

\section{Introduction}

Dejection, the state of one who doesn't have a commonplace or socially satisfactory proportion of money or material effects. Dejection is said to exist when people don't have the best approach to satisfy their fundamental needs. In this particular condition, the unmistakable evidence of down and out people at first requires a confirmation of what contains basic needs. These may be described as scarcely as "those central for perseverance" or as extensively as "those reflecting the all-encompassing lifestyle in the organization." The essential model would cover only those people near the edge of starvation or passing from presentation; the second would contact people whose sustenance, housing, and dress, anyway adequate to spare life, don't coordinate those of the general population with everything taken into account. The issue of definition is moreover exacerbated by the noneconomic feelings that the word destitution has picked up. Desperation has been connected, for example, with persistent shortcoming, low degrees of guidance or capacities, a disappointment or a hesitance to work, high movements of dangerous or offense, and improvidence. While these qualities have consistently been found to exist with desperation, their joining in a significance of destitution would will when all is said in done cloud the association among them and the inability to oblige one's fundamental needs. Whatever definition one uses, authorities and laypersons the equivalent ordinarily expect that the effects of destitution are dangerous to the two individuals and society.[1-5]

2. Objectives:

$>$ To study the Poverty and Its Causes in India

$>$ To study the types of poverty 


\section{Methodology:}

The methodology is incredibly needed to construct the analysis work equally qualitative and quantitative ways in which were used within the study. This text has required secondary data, secondary data has been collected from written offer, like varies periodicals, articles, reports, books, journals, and literatures, on the subject. For the aim of gathering the most recent updated information's on the topic e-sources to boot sharpeyed.

\section{Factors of Poverty:}

Induction to extraordinary schools, clinical consideration, power, safe water, and other fundamental organizations remains inconspicuous for a few and is every now and again constrained by money related status, sex, character, and geography. For those prepared to move out of destitution, progress is as often as possible brief. Budgetary shocks, food slightness, and ecological change bargain their advantages and may force them back into destitution.

Desperation is an inconvenient cycle to break and every now and again went beginning with one age then onto the following. Basic results of destitution join alcohol and substance abuse; less permission to preparing; powerless housing and ordinary conditions, and extended degrees of ailment. Raised desperation is likely going to cause extended strains in the public field, as difference increases. These issues consistently lead to expanding wrongdoing rates in networks impacted by destitution.

\section{Cyclical Poverty:}

Rehashing poverty implies desperation that may be extensive all through a general population, yet the occasion itself is of limited range. In nonindustrial social requests (present and past), such an inability to oblige one's basic needs rests generally upon ephemeral food inadequacies achieved by trademark marvels or poor plant masterminding. Expenses would ascend because of deficiencies of food, which brought all over, however fleeting, misery.

In industrialized social requests the manager redundant explanation behind desperation is fluctuations in the business cycle, with mass joblessness during seasons of unhappiness or authentic decline. All through the nineteenth and mid 20th many years, the industrialized nations of the world experienced business crazes and slumps that quickly enlarged the amounts of needy individuals. The United States' inclusion with the Great Depression of the 1930s, anyway fascinating in a part of its features, exemplifies such a dejection. Additionally, until the Great Depression, poverty coming about in light of business changes was recognized as a certain aftereffect of a trademark pattern of market rule. Mitigation was permitted to the jobless to hold them over until the business cycle again entered an ascent. The experiences of the Great Depression stirred a period of budgetary specialists, for instance, John Maynard Keynes, who searched for answers for the issues achieved by preposterous swings in the business cycle. Since the Great Depression, governments in basically completely advanced mechanical social requests have gotten budgetary techniques that try to confine the detestable effects of financial change. In this sense, governments expect a working part in desperation facilitating by extending spending as a strategies for empowering the economy. Part of this spending comes as prompt assistance to the jobless, either through joblessness compensation, government help, and various allotments or by deal with open works adventures. Notwithstanding the way that business depressions impact all sections of society, the impact is commonly genuine on people of the least budgetary layers since they have less minor resources than those of higher layers. [6-9]

\section{Collective Poverty:}

Instead of intermittent poverty, which is transient, inevitable or "total" dejection incorporates a modestly enduring insufficiency of expects to ensure about fundamental needs a condition that may be so wide as to portray the ordinary level of life in an overall population or that may be moved in commonly gigantic gettogethers in a for the most part prosperous society. Both summarized and figured total desperation may be imparted from forever, gatekeepers giving their destitution to their children.

Total destitution is modestly expansive and suffering in parts of Asia, the Middle East, a huge bit of Africa, and parts of South America and Central America. Life for the primary aspect of the general population in these areas is at a unimportant level. Dietary needs cause disease seldom saw by masters in the extraordinarily 


\section{www.rspsciencehub.com}

developed countries. Scoundrel trust, huge degrees of infant youngster mortality, and constant shortcoming depict life in these social requests.

Total destitution is normally related to budgetary underdevelopment. The total resources of many making nations in Africa, Asia, and South and Central America would be missing to help the general population adequately whether or not they were also disengaged among the aggregate of the inhabitants. Proposed fixes are twofold: (1) advancement of the gross public thing (GNP) through improved cultivating or industrialization, or both, and (2) people hindrance. So far, both people control and provoked monetary improvement in various countries have exhibited inconvenient, questionable, and sometimes dubious or baffling in their results. [10-15]

An extension of the GNP doesn't generally incite an improved lifestyle for the general population all over the place, for different reasons. The most critical clarification is that, in many making countries, the general population turns out to be significantly snappier than the economy does, with no net lessening in poverty in this way. This extended people advancement stems fundamentally from cut down infant passing rates made possible by improved clean and ailment control measures. But on the off chance that such cut down rates unavoidably achieve women bearing less children, the result is a sharp accelerating in people improvement. To reduce birth rates, some making countries have endeavored comprehensively coordinated familymasterminding programs, with evolving results. Many making nations are in like manner depicted by a long-standing course of action of conflicting dissemination of wealth a system inclined to continue paying little mind to checked augmentations in the GNP. A couple of experts have viewed the tendency for a colossal section of any extension to be diverted by individuals who are currently rich, while others ensure that increases in GNP will reliably gush down to the part of the general population living at the methods level.

\section{Concentrated Collective Poverty:}

In many industrialized, modestly rich countries, explicit portion packs are vulnerable against long stretch dejection. In city ghettos, in locale evaded or gave up by industry, and in areas
Volume 02 Issue 10S October 2020

where cultivating or industry is inefficient and can't battle beneficially, there are found losses of concentrated total destitution. These people, like those tortured with summarized poverty, have higher passing rates, ongoing slightness, low educational levels, and so forth when differentiated and the more regal parts of society. Their supervisor financial credits are joblessness and underemployment, uncouth occupations, and work wobbliness. Tries at upgrade base on ways to deal with convey the prevented packs into the norm from getting money related life by pulling in new industry, propelling privately owned business, introducing improved agrarian procedures, and raising the level of aptitudes of the employable people from the overall population.

\section{Case Poverty:}

Like total poverty in relative interminable quality anyway not equivalent to it with respect to movement, case desperation implies the disappointment of an individual or family to ensure about basic needs even in social ecological components of general flourishing. This frailty is normally related to the nonattendance of some fundamental quality that would permit the individual to keep up oneself. Such individuals may, for example, be outwardly impeded, genuinely or truly weakened, or perseveringly wiped out. Physical and mental debilitations are ordinarily regarded nicely, as being outside the capacity to control of the people who experience the evil impacts of them. Attempts to improve destitution due to physical causes revolve around guidance, protected work, and, if essential, budgetary help.

\section{Types of Poverty:}

On the basis of social, economical and political aspects, there are different ways to identify the type of Poverty:

9.1 Absolute poverty: In any case called uncommon poverty or despicable dejection, it incorporates the deficiency of basic food, clean water, prosperity, refuge, guidance and information. The people who have a spot with out and out desperation will by and large fight to live and experience a lot of youth passings from preventable ailments like wilderness fever, cholera and water-spoiling related disorders. Preeminent 


\section{www.rspsciencehub.com}

Poverty is regularly excellent in developed countries.

9.2 Relative Poverty: It is portrayed from the social perspective that is desire for ordinary solaces appeared differently in relation to the monetary standards of people living in ecological elements. Accordingly it is an extent of pay unevenness. For example, a family can be seen as poor if it can't shoulder the expense of outings, or can't tolerating presents for kids at Christmas, or can't send its young to the school.

By and large, relative desperation is assessed as the degree of the general population with compensation not actually some fixed degree of center compensation. It is a comprehensively used measure to decide desperation rates in rich made nations.

9.3 Situational Poverty: It is a concise sort of destitution subject to occasion of a negative event like common catastrophe, work hardship and outrageous clinical issue. People can help themselves with night with a little assistance, as the poverty comes because of tragic event.

9.4 Generational Poverty: It is offered over to individual and families from one age to the one. This is more puzzled as there will never be an exit plan in light of the fact that people are trapped in its inspiration and unable to receive to the mechanical assemblies required getting consequently.

9.5 Rural Poverty: It occurs in nation regions with people under 50,000 . It is the place there are less openings for work, less permission to organizations, less assistance for ineptitudes and quality preparing openings. People are tending to live for the most part on the developing and other unobtrusive work available to the ecological components.

9.6 Urban Poverty: It happens in the metropolitan territories with populace more than 50,000. These are some significant difficulties looked by the Urban Poor:

- Limited access to health and education.

- Inadequate housing and services.
Volume 02 Issue 10S October 2020

- Violent and unhealthy environment because of overcrowding.

- Little or no social protection mechanism.

\section{Conclusion:}

Destitution has become an exceptional issue in our existence. Regardless of the way that various affiliations have been made to find answers for this issue nobody couldn't extra our world absolutely from dejection. The most broadly perceived reality which we can comprehend when we consider on information about poverty is that dejection is by and large occurring in making countries.

What are the impacts of destitution for our reality? Do you realize that more than 21,000 kids bite the dust each day around the globe because of diseases, clashes on the planet and other various reasons? The majority of these are brought about by destitution.

As a young understudy, I should propose a couple of parts which would be helpful in our outing to diminish dejection. Basically we have to figure out how to reduce the general population in our existence. Trademark resources don't extend as demonstrated by the general population which is growing at a quick. Right when we consider the families in powerless countries, they have in any occasion six or seven youngsters. However, those kids don't have a suitable prosperity or the gatekeepers can't give authentic preparing to them. Also, besides those watchmen can't outfit incredible sustenances stacked up with sensible enhancements to their youngsters due to nonattendance of wealth. Because of that their quality decreases by a broad aggregate. The progression of their psyches gets lacking and due to that their ability to get suitable preparing lessens.

So figuring out how to make prosperity and preparing parts in these countries is a nice technique to lessen poverty. So at first we have to make organizations for pregnant women of those countries and outfit them incredible sustenances stacked up with fitting enhancements to keep the youngsters solid. What's more, a short time later the youngsters will be solid and their brains will be in a better condition than get authentic guidance. Working up the preparation parts of those countries with the help of respectable purpose organizations and the governing bodies of made 
www.rspsciencehub.com

countries is in like manner a good development to make guidance structures in those countries.

\section{References:}

[1].https://en.wikipedia.org/wiki/Poverty_in_I ndia

[2]. Vicious Circle of Poverty and the Scarcity of Capital, available at http://www.economicsdiscussion.net/pover t y/problem-poverty/the-problem-ofpovertyin-india-an-overview/12842(last visited on 21st December 2019)

[3].Chandra Shekhar Gupta Boggarapu, "Poverty in India", Notion Press, Inc; 1 edition (23 May 2018)

[4].Poverty in India, available at https://www.indiacelebrating.com/socialissues/poverty/ (last visited on 24nd December 2019).

[5].Poverty as a Challenge, available at https://www.toppr.com/guides/economics/p overty-as-a-challenge/poverty/ (last visited on 23rd December 2019)

[6].S Mahendra Dev, 'Inclusive Growth in India', Oxford University Press 2007, Oxford India Paperbacks 2010

[7]. Amartya Sen, "Poverty and Economic Distribution in India", Juggernaut Publication, Revised edition (5 April 2017)

[8]. Main Causes of poverty in India, available at

http://www.economicsdiscussion.net/pover

t $\quad \mathrm{y} /$ problem-poverty/the-problem-ofpovertyin-india-an-overview/12842(last visited on 22nd December 2019).

[9].Poverty in India: Facts, Causes, effects, Injustice and Exclusion, available at https://www.poverties.org/blog/povertyinindia(last visited on 22nd December 2019)

[10].Comparison between Rural and Urban Poverty in India, available at http://www.yourarticlelibrary.com/poverty/ c omparison-between-rural-povertyandurban-poverty-of-india/32149 (last visited on 24th December 2019).

[11].NRLM, available at, https://aajeevika.gov.in/ (last visited on 24th December 2019).
Volume 02 Issue 10S October 2020

[12].Fight Hunger First Initiative, available at https://welthungerhilfeindia.org/initiative/fi ght-hunger-first-initiative-2/ (last visited on 24th December 2019).

[13].Poverty Estimation in India, available at https://www.drishtiias.com/tothepoints/paper3/poverty-estimation-inindia (last visited on 22nd December 2019).

[14].Farm loan Waiver, available at, https://www.india.com/topic/farmloanwaiver/ (last visited on 24th December 2019).

[15].UN endorses India's steps to address hunger, malnutrition, available at https://newsd.in/un-endorses-india-sstepsto-address-hunger-malnutrition/ (last visited on 24th December 2019). 